\title{
Analysis on differences in Canada and China's official attitude and perception on their minority nationalities
}

\author{
Dennis Song*, dennissong2020@163.com
}

\begin{abstract}
The government's perceptions and attitudes of their ethnic minorities are in close relation with the ethnic minorities' welfare policies, and also affect the public's perception of ethnic minorities. Therefore a government's definition and attitudes are crucial to maintaining national stability. For instance, Canada is a multi-nation state, comprising multiple ethnic groups in one country, with the two most influential as the FrenchCanadians and the English-Canadians. French and English Canadians are majority ethnic groups while there are many other minority ethnic groups such as the First Nations. The People's Republic of China is also a multi-nation state, although the biggest ethnic group, the Hans, comprise $98 \%$ of the entire population. ${ }^{11}$ Although all nations have their own cultural cognition - common descent, history, culture, and language - both Canada and China have their own unique definition for their minority nations: Canada's minority nations are the Aboriginal People of Canada ${ }^{22}$, and China's minority nations are the 55 officially recognized ethnic groups other than the Han people. This essay aims to compare the official perceptions and attitudes of ethnic minorities in China and Canada, hoping to clarify the relationship between ethnic minorities and mainstream ethnic groups, and help the general public to understand them, hence promoting harmonious societal development.
\end{abstract}

KEYWORDS: Europeans, Travelers, Missionaries, Muslims, description

1 The Permanent Mission of the People's Republic of China to the United Nations Office in Geneva and Other International Organizations in Switzerland. Regional Ethnic Autonomy in China, 2003 2For compare and contrast purposes, the Canadian minorities in this article will only be referring to the Aboriginal people of Canada, excluding other minority nations such as Black Canadians.

Naming the minorities: insight to official definition and recognition of Aboriginal People of Canada

Aboriginal people of Canada: refers to the first inhabitants of Canada, and includes First Nations, Inuit, and Métis peoples

First Nations: refers to Aboriginal peoples of Canada who are ethnically neither Métis nor Inuit

Inuit: groups of people generally living in the far north who are not considered "Indians" under Canadian law

Métis: refers to a collective of cultures and ethnic identities that resulted from unions between Aboriginal and European people in what is now Canada.

The Aboriginal people of Canada are commonly known in public as "First Nations". However, according to the Report on the Royal Commission on Aboriginal Peoples, theterm "Aboriginal" is not interchangeable with the term "First Nation". The term "First People of Canada" include First Nations who were originally referred to as Indians and Inuits (who had never been considered as Indians in history), and the term "Aboriginal People" can refer to First Nations, Inuits, and Metis (section 35(2) of the Constitution Act, 1982).

According to the Canadian Encyclopedia, an online encyclopedia funded by the Government of Canada and run by Historica Canada, the term "First Nations" is defined as "original inhabitants of the land that is now Canada and were the first to encounter sustained European contact, settlement and trade", which means that both Inuit and Metis people of Canada are excluded from the "First Nations" title.

The term Inuit includes the majority of people who inhabit the northern regions of Canada. Usually generalized as native inhabitants of Nunavut and Northwest Territories, Inuit people inhabit places from Alaska to Greenland, including northern Quebec. Inuits are excluded from the term First Nations for many reasons: firstly due to their considerable differences in culture resulted from different physiographic regions; second due to their later contact with the Europeans (ex. the Inuits did not participate in the Seven Years War and colonization did not violently occur in the early stages of New France up north due to the absence of beavers for fur trading and incapability of farming). The Inuits of Quebec and Labrador, although considered to be Inuits of Canada on legal documents, prefer to refer themselves as Innus, distinctive from the grand term Inuits due to their greater differences in culture and language 
and more impactful in early interactions with the French and Spanish in fur trading. Thus calling the Inuit and Innu as First Nations would be incorrect; the correct term should be the First People of Canada.

The Metis people are the descendants of the original French fur traders, who were the first people to encounter the First Nations. However, due to intermarriage between the First Nations and Europeans, the Metis people evolved to have unique traditions, identities, and ways of life, thus they are distinctive from Europeans and First Nations. Due to their significant involvement in fur trading before their so-called territories became Canada, they are considered as Aboriginal People of Canada. Although the Metis are sometimes neglected as part of the Aboriginal community (due to non-distinctive clothing, skin-colours, eye-colours, etc.) they are considered as Aboriginal people of Canada by law. For example, the Supreme Court of Canada ruled inDaniels v. Canada (Indian Affairs and Northern Development)that Métis and non-status Indians are considered Indians under s. 91(24) of the 1982 Constitution (Johnson, 2019), setting legal rights for Metis to enjoy the same rights as the First Nations.

\section{Residential schools: metonymy for the government's shift in attitude}

The Government of Canada's attitude towards the First Peoples has changed significantly during the course of history: noticeably turning away from a 'white supremacist' attitude. When Samuel de Champlain founded New France in the 16th century, and for the next 400 years, the First People's lands were stripped away from them and the practice of their culture was forbidden. No one knows what happened to the St. Lawrence Iroquois: did they really simply just 'disappear', as referred to as in the textbooks, because they peacefully cohabitated with the French and were "white-washed" due to intermarriage? ${ }^{1}$ No one knows the origin of Thanksgiving Day: did the First Nations really enjoy "salt beef, biscuits and mushy peas to celebrate and give thanks for [the french]'s safe arrival in what is now Nunavut"2? Nevertheless, what happened for sure was the long-going residential school's operation across Canada between the 1870s and the 1990s, where the white settlers stripped children away from their homes and tried to inhumanely convert them into 'white culture'.

The shift in the government's attitude reflected most visibly upon the matter of residential school. Residential schools were established by the government and the church, with goals to assimilate Indigenous children into a white-European lifestyle. The first residential school started to admit children in the winter of 1831 , and over the next century another 130 schools would operate coast to coast. ${ }^{3}$ Children in these schools were forbidden to practice indigenous cultures of any sort. They were stripped away from their homes, told that shamanism was 1 Gagné, Michel. "St Lawrence Iroquoians". The Canadian Encyclopedia, 04 March 2015, Historica Canada 2 Mills, David et al. "Thanksgiving in Canada". The Canadian Encyclopedia, 05 July 2019, Historica

Canada

3 Miller, J.R.. "Residential Schools in Canada". The Canadian Encyclopedia, 25 June 2020, Historica Canada. a practice of demons, and encountered abuses. These schools were powerful: they had the blessing from all major churches and the support from John. A. Macdonald ${ }^{4}$, the first PM of Canada. However, resistance from the aboriginal community was always visible - parents hid their children, children tried escaping, and boys set schools on fire.

January 1, 1948: students cheered while watching Thunderchild Indian Residential School burn down by fire set by four boys.

\section{October 23, 1966: Chanie Wenjack died trying to escape} the holy hell.

July 24, 1976: Île-à-la-Crosse Residential School closed down due to a series of fires in 1964 and $1972^{5}$.

Someone's violence works best. It was not long after the Oka Crisis, a land dispute between a group of Mohawk people and the town of Oka, that the federal government realized that cultures cannot be washed away in a modernizing world and started the long-lasting and on-going process of reconciliation.

At least the modern government of Canada realized their mistakes and started to reconcile. Laws and regulations are shadows to a government's attitude towards the subject matters, hense by looking at changes made to the Indian Act of 1876 6, the government's shift in attitude can be better comprehended. The predecessor of the Indian Act of 1876 was The Gradual Enfranchisement Act or The Gradual Civilization Act of 1857. As its name suggested, The Gradual Civilization Act aimed to "assimilate the Indian people in all respects with the other inhabitants of the Dominion as speedily as they are fit to change," 7 quoted from John. A. Macdonald, the first Prime Minister of Canada. From this, it can be seen that the government never included Aboriginal culture to be part of the future of Canada. Even more, the government of Canada used the hands of religion to "isolate children from ... their homes, families, traditions and cultures, and to assimilate them into the dominant culture." The Indian Act once quoted that "the Minister [may] ... enter into agreements ... with ... a religious ... organization" ${ }^{8}$ to host the Indigenous children's education. These laws reflect the past ties of the Canadian government with churches and the racist ideology of religion supremacism. This theme of white religion being more majestic than Aboriginal religion is further expanded by the amount of respect Catholicism and Protestants are receiving. The act also stated that "Every Indian child who is required to attend school shall attend such school as the Minister may designate, but no child whose parent is a Protestant shall be assigned to a school conducted under Roman Catholic auspices and no child whose parent is a Roman Catholic shall be assigned to a school conducted under Protestant auspices,

4 Beazley, Doug. "Decolonizing the Indian Act." CBA National Magazine, 18 Dec. 2017

5 Beazley, Doug. "Decolonizing the Indian Act." CBA National Magazine, 18 Dec. 2017 6 Legislative Services Branch. "Consolidated Federal Laws of Canada, Indian Act." Indian Act, 19 Aug. 2020 7 Beazley, Doug. "Decolonizing the Indian Act." CBA National Magazine, 18 Dec. 2017

8 Legislative Services Branch. "Consolidated Federal Laws of Canada, Indian Act." Indian Act, 19 Aug. 2020 
except by written direction of the parent." This regulation shows the government's clear consciousness of respecting people's beliefs; however, this regulation clearly shows the disrespectfulness the white government had towards the Aboriginal people. How can the government respect people's choice of Protestant Church or Catholic Church while disapproving of the Aboriginal people's choice of their own culture? Hence, the aforementioned regulations show the dehumanizing cognition that the government had on the Aboriginal people in the 19th and 20th centuries.

It took many great courageous actions to change the government's attitude, and even more efforts to impact legislation. Dr. Peter Henderson Bryce published The Story of a National Crime, ${ }^{10}$ trying to raise awareness of the negligence of children's health in residential schools in the spring of 1922; however, it would take another 40 years for the government to finally take action to respond to the tremendous health problems that residential school was causing. Many of these courageous actions were indeed very violent. Gruesome, but effective and persuasive. How much suppression was put upon the children in order for young teenagers to burn down the Thunderchild Indian Residential School? And how much dehumanizing experiences did the children endure, for them to "cheer as they watch the school burn"? "The Canadian government [finally took] over responsibility for the remaining residential schools from the churches"11 in 1969. It was an action that reflected the Cold War technology bloom: if the Qubecois' Quiet Revolution had seen effects by them turning away from the farm, family, and faith ideology, then perhaps religion was not the best route to provide education for First Nations?

When the government realized that reconciliation was in critical need, "more than 20,000 First Nation, Métis and Inuit children [were] 'scooped from their homes ... leaving many [of them] with a lost sense of cultural identity"12, in the sixties alone. However, reconciliation was a crucial action that represented Canada's Cold War strategy: be THE middle power and befriend everyone. How can a nation befriend other nations when it cannot create peace amongst its citizens? It was a long and on-going process. The Final Report of the Royal Commission on Aboriginal Peoples can be regarded as the initiator of reconciliation, as the 4000 pages report asked for "a public inquiry into the effects of residential schools, including language loss and trauma."13 Then comes the establishment of the Truth and Reconciliation Commission (TRC), a commission goaled to acknowledge and heal residential school histories. The Formal Apology to Former Residential Schools Students was delivered in the summer of 2008: "The treatment of children in Indian Residential Schools is a sad chapter in our history", started PM Harper, and "strong 9 Legislative Services Branch. "Consolidated Federal Laws of Canada, Indian Act." Indian Act, 19 Aug. 2020 10 Bryce, Peter Henderson. The Story of a National Crime, Being an Appeal for Justice to the Indians of Canada. J. Hope, 1922.

11 Miller, J.R.. "Residential Schools in Canada". The Canadian Encyclopedia, 25 June 2020, Historica 11 Miller,

12 Miller, J.R.. "Residential Schools in Canada". The Canadian Encyclopedia, 25 June 2020, Historica

Canada.

13 Miller, J.R.. "Residential Schools in Canada". The Canadian Encyclopedia, 25 June 2020, Historica Canada. [aboriginal] communities and vibrant cultures and traditions will contribute to a stronger Canada for all of us,"14 ended PM Harper. The delivered speech is an obvious representation of the shift in attitude from the Canadian Government: from 'we will use white religion to cleanse you savages' to 'Aboriginal cultures and traditions are a national treasure to the multicultural Canada', as it should have always been.

\section{Examples of how China groups cultural minorities}

As a multi-nation state, the cultural minorities of China are defined by the People's Republic of China to be all ethnic groups aside from the majority ethnic group: the Han nation, which comprises around $91 \%$ of the entire Chinese population (2010 census). The cognition of 55 minority ethnic groups was invented after the founding of New China (1949). The concept of individual groups were decided by multiple factors: culture, history, etc.

Unlike how the Canadian government officially recognizes individual First Nation groups, the Chinese government sometimes prefers to group smaller cultural minorities groups together to form a bigger ethnic group with similar identifying features. For example, the Canadian Kwikwasut'inuxw Haxwa'mis First Nation calls themselves the Kwikwasut'inuxw Haxwa'mis People; therefore the BC Government acknowledges their presence and right to self-association; even though they have a relatively small population of only $312^{15}$ (2016), they are still considered as one unique and distinctive nation. However, the Chinese Gaoshan ethnic group is made up of many other 'sub-groups', each preferred to be identified as their initial 'sub-group', at least during the early stages of New China. There are currently 13 confirmed Gaoshan ethnic 'sub-groups' in Taiwan, which includes Babusa, Basai, Hongya, Ketagalan, etc. ${ }^{16}$ For instance, if these 13 ethnic groups were grouped by the Canadian method of taxonomy, then the Gaoshan ethnic group would not technically exist. To summarize, the Canadian government differentiates their First Nation groups as their community name, while the Chinese government sometimes prefers to group smaller ethnic groups that share a similar geographical identity together to form a bigger ethnic group for easier classification.

Another notable aspect that the Chinese government used to identify ethnic groups is common culture and history. Many Chinese ethnic groups are so-called "cross-state nations", which means these nations have a considerable population even outside of China. These "cross-state nations" can be the descents of a foreign state, or simply a segment of a larger nation that happens to have a population in China. Examples of the former one would be the Chaoxian people, which are the descendants of the people that originally migrated from ancient Korea, and the Hui people, whose ancestors are believed to be Islamic Persians who migrated into Mongolian China in the

\footnotetext{
14 Harper, Stephen. "Indian Residential Schools Statement of Apology - Prime Minister Stephen Harper." Government of Canada; Indigenous and Northern Affairs Canada; Communications Branch, Government of Canada, 15 Sept. 2010

15 Ministry of Aboriginal Relations and Reconciliation. "Kwikwasut'inuxw Haxwa'mis First Nation." Prov ince of British Columbia, Province of British Columbia, 26 Aug. 2019 16 Guo, Zhen. "The Gaoshan People." Central Government Portal, 2013
} 
13th century. Fun fact: in the traditional Wa people's language, the Hui people are referred to as "Basi", which directly means "the people from Persia 17". An iconic example of the latter one would be the Dai people. 'Dai', is the name that the PCR officially recognizes the Tai peoples that happen to live in the borders of modern China. The Tai peoples are simply the people whose culture is heavily influenced by mainland southeast Asia and the river valleys. Divided and populated in multiple states, each individual governments name them differently: Thailand, Vietnam, and Cambodia name them 'Thai', Laos calls them 'Lao', Myanmar refers them as 'Shan', and India titles 'Ahom'.

The official attitude of the PRC towards ethnic minorities can be clearly seen through the common motif of "unity for all cultures" in their propaganda. Below is an iconic example of propaganda of Chinese patriotism through the motif of cultural unity. The caption "I love my country! 56 ethnic groups sing this song together" Yu, Xinxin. "I love my country! 56 ethnic groups sing this song together." People's Daily-Quality News, 201918 literally means "I love my country! 56 ethnicities sing this song together". It should be noted that there are only 55 minority groups that the PRC recognizes, hence the Han people is also included in the caption; therefore it can be seen that press and media is aiming to spread the idea the cultural minorities are not different from the Hans, and vice versa.

This motif is a shadow of the ideology of Zhonghua

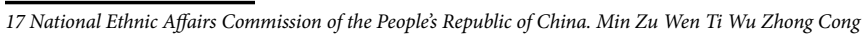
Shu. Min Zu Chu Ban She, 2007.

18 Yu, Xinxin. "I love my country! 56 ethnic groups sing this song together." People’s Daily-Quality News,

2019
Minzu (the Chinese nationality), an ideology emphasised by the government to promote national unity. The key concept of Zhonghua Minzu is the construction of a new "Chinese nation", which comprises all 56 nations. One thing to note from the government's ways of promoting Zhonghua Minzu to the general public is its emphasis on "the same origin" by using mythology. In Baidu Baike, the predominant online encyclopedia used in mainland China, the "Yanhuang mythical era" can be found in many pages of ethnic minorities in describing their origins. For example, in the Miao people's entry in Baidu Baike, it is described that "after the defeat of Chiyou's Jiuli ... most of [Miao people] migrated south ... [t] he legend of Chi You is still widely circulated among the Miao people, and they have always believed in Chi You as their ancestor"19 . Not only does propagandizing Zhonghua Minzu diminish the differences in origin and gaps between minority nations and the Hans, but also sets the stage for cultural equity in the future.

The minority groups are also seen as socially vulnerable people by the government - this can be seen through the government's special welfare policies and beautifying stereotype building. There are indeed many special treatments that the government has for ethnic minorities: extra points awarded for Gaokao, extra children per household, even under the regime of One Child Policy, and extra lenient on crimes. From the government's emphasis on population growth we can see that the attitude the PRC has towards ethnic minorities is very protective. The Chinese cultural minorities often appear in official settings as young girls with their shiny traditional

19 Baidu Baike. "Miao Nationality." Baidu Baike, 2009

人a秋有品质的新闻

\section{我爱我的国！56个民族同唱这首歌}

人民日报客户端 2019-09-26 08:18 汶览量246.7万

\section{这是最真挚的告白}

饱含最炽热的情感

从莽莽兴安到雪域高原

从繁华都市到碧波南海

这是 56 个民族爱的表达

是我们心底里流淌出来的歌

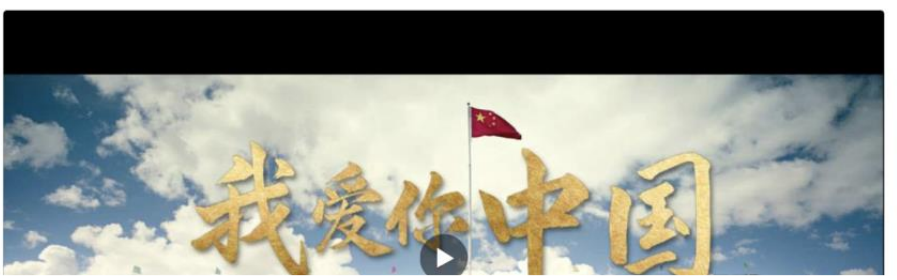

Figure 1: Screenshot of Yu, Xinxin. “I love my country! 56 ethnic groups sing this song together.” People's Daily-Quality News, 2019 
outfits, which helps create the public image that people of cultural minorities are tender, gentle, and soft. In conclusion, from the government's branding and special policies for ethnic minorities, the attitude towards these people can be seen as: lack of access to a modernized world, no good publicity packaging, poor economic foundation, small population base, therefore their customs and cultural inheritance are easily lost.

\section{CONCLUSION}

Official cognition and attitudes of countries towards their minority nations changes throughout the course of history. The Canadian government realized that the Indigenous people are treasures of the countries' cultural foundation, and the Chinese government realized the cultural minorities' dream of becoming the "true master of their own country". What can be seen is societies are becoming more harmonious around the world. Supremacy ideologies have faded, and minorities have made themselves heard. At last I want to address that it is the people's choice to associate with a certain nation and the government has the responsibility to acknowledge the choice of the nation as humanly as possible.

\section{REFERENCES}

1. The Permanent Mission of the People's Republic of China to the United Nations Office in Geneva and Other International Organizations in Switzerland. Regional Ethnic Autonomy in China, 2003, www.china-un. ch/chn/zywjyjh/t185070.htm.

2 .

3. Gagné, Michel. "St Lawrence Iroquoians". The Canadian Encyclopedia, 04 March 2015, Historica Canada. https://www.thecanadianencyclopedia. ca/en/article/st-lawrence-iroquoians. Accessed 27 August 2020.

4. Mills, David et al. "Thanksgiving in Canada". The Canadian Encyclopedia, 05 July 2019, Historica Canada. https:/www.thecanadianencyclopedia. ca/en/article/thanksgiving-day. Accessed 27 August 2020.

5. Miller, J.R.. "Residential Schools in Canada". The Canadian Encyclopedia, 25 June 2020, Historica Canada. https://www.thecanadianencyclopedia. ca/en/article/residential-schools. Accessed 27 August 2020.
6. Beazley, Doug. "Decolonizing the Indian Act.” CBA National Magazine, 18 Dec. 2017, www.nationalmagazine.ca/en-ca/articles/law/opinion/2017/ decolonizing-the-indian-act.

7. Legislative Services Branch. "Consolidated Federal Laws of Canada, Indian Act." Indian Act, 19 Aug. 2020, laws-lois.justice.gc.ca/eng/ acts/i-5/page-14.html\#h-332928.

8. Bryce, Peter Henderson. The Story of a National Crime, Being an Appeal for Justice to the Indians of Canada. J. Hope, 1922.

9. Harper, Stephen. "Indian Residential Schools Statement of Apology Prime Minister Stephen Harper." Government of Canada; Indigenous and Northern Affairs Canada; Communications Branch, Government of Canada, 15 Sept. 2010, www.rcaanc-cirnac.gc.ca/eng/1100100015677/1 571589339246.

10. Ministry of Aboriginal Relations and Reconciliation. "Kwikwasut'inuxw Haxwa'mis First Nation." Province of British Columbia, Province of British Columbia, 26 Aug. 2019, www2.gov.bc.ca/gov/content/ environment/natural-resource-stewardship/consulting-with-first-nations/ first-nations-negotiations/first-nations-a-z-listing/kwicksutaineuk-ahkwa-mish-tribes.

11. Guo, Zhen. "The Gaoshan Nationality.” Central Government Portal, 2013, www.gov.cn/test/2006-04/14/content_254240.htm.

12. National Ethnic Affairs Commission of the People's Republic of China. Min Zu Wen Ti Wu Zhong Cong Shu. Min Zu Chu Ban She, 2007.

13.

14. Yu, Xinxin. "I love my country! 56 nationalities sing this song together." People's Daily-Quality News, 2019, wap.peopleapp.com/ article/4629339/4511365.

15. National Ethnic Affairs Commission of the People's Republic of China. "China's Ethnic Minority Policy and Practice." China Government Website, 1999, www.neac.gov.cn/seac/xwzx/199909/1010525.shtml.

16.

17. Baidu Baike. "Miao." Baidu Encyclopedia, 2009, baike.baidu.com/ item $/ \% \mathrm{E} 8 \% 8 \mathrm{~B} \% 97 \% \mathrm{E} 6 \% 97 \% 8 \mathrm{~F}$. 